\title{
SULTAN SULEIMAN THE MAGNIFICENT AT THE GATES OF VIENNA
}

\section{E. San Juan, Jr.}

\section{About the Author}

E. San Juan, Jr. was recently a fellow of the W.E.B. Du Bois Institute, Harvard University, and of the Harry Ransom Center, University of Texas. He has taught at various universities in the world, including Leuven University, Belgium; Tamkang University, Taiwan; University of Trento, Italy; Ateneo de Manila and the University of the Philippines. He is recently a professorial lecturer at the Polytechnic University of the Philippines. His most recent books are Lupang Hinirang, Lupang Tinubuan (2015) and Between Empire and Insurgency (2015). 
A provocative original voice enters the archive of Philippine writing in English with Charlie Samuya Veric's Histories. Time unfolds in places that catalyze imagination. From New Haven to Gaza, Diliman, Alexandria, New York, Vienna, Escolta, and everywhere, this Filipino artificer of words interrogates life-histories in specific locales that bear common indices: solitudes, dreams, desires. He deploys in urbane global English what used to be called "international style" coeval with the cosmopolitanized market of the imperial bourgeoisie (as Marx and Engels noted). Veric succeeds wonderfully in giving us a savor of this style without budging from our seats, in real time.

As expected in our intellectual/academic milieu, the poet resists our daily disappearance into "the mill of Robinson's Place." He protests against the varied locales of commodified life that ironically swallows difference. Representing the multitude of alienated "others," the poet cries out for recognition of individualities, for singularity, for freedom: "I write, therefore, I am freed from rote life." It is the classic predicament of Villa, Kafka, Dostoevsky, Joyce, etc. The poet's anguish springs from the modernist impulse of defying Cartesian clocktime with "nonsynchronicities," sometimes with the postmodern pastiche or baroque now a universal poetic idiom. He strives to fuse the now and the eternal into one epiphanic moment of recognition; the traditional metaphor used is Dante's vision of Beatrice. Who is Beatrice in the last poem of the book, "Vita Nova"? Writes Veric:

Tuesday when the weather clears up. Urban birds,

framed by the soldered metal of the fire exit, are singing.

Someone reads in bed. He stops to listen to the singing.

Eyes the narcoleptic blue out the condo.

He props the book open on his chest. Imagines.

Crystal mountains throb and swirl and dance in accord like star-dust.

No dullness anywhere visible or thinkable.

John Muir on his first summer in the Sierra, writing in 1869

about lizards on hot rocks, shrub beside cool streams,

hazel and dogwood thickets. 
Shifting in bed, he recalls the Guardian article on his $F B$ feed,

which names now the age of loneliness, its toxicity

twice deadlier than smoking or being overweight.

We're not made for this, the article says,

jacking off to online porn to lick our wounds.

Again and again, as I lingered over these charming plants, I said,

How came you here? How do you live through the winter?

He thinks of midnights with Youtube, jogs in the rain,

walks from Avenida to Escolta, stops at Pureza,

beloved station of a Buena extranjera who's back in Barcelona, massages at Beijing Spa.

The species is Lilium pardalinum, five to six feet high, leaf-whorls a foot wide,

flowers about six inches wide, bright orange, purple spotted in the throat, segments revolute-a majestic plant.

They say he's lonely. Why can't they say he's free?

This last poem is an intriguing sign of a promise that I am sure Veric (always true to his name) will make good in his next work. Walter Benjamin once said that the self is the most powerful opium we suck every time we are lonely. And so we are provoked to query: Is solitude a sign of freedom? In my reading, it is a symptom or allegory of that market-centered history the poet rejects in so many nuanced images and tones. We share his anguish in making multiple "histories" to resist a homogenizing, monolithic narrative of our human condition.

For the common reader to freely appreciate this book, she needs to discover meanings in Veric's expressive gestures and communicate them. Such communication is premised on a solidarity of linked backgrounds, shared understandings. Solitude is thus released from its monadic framework, the egocentered discourse of modernity. The poet's motive is, I surmise, to create this 
planetary platform for conviviality. Based on my acquaintance with his work, Veric seeks to be a planetary poet. We might then place this book in the milieu of world literature, first conceived by the romantic Goethe, where national context is a prerequisite for there to be free, equal articulation among languages and cultures.

And so our task as readers is geopolitical triangulation: Where can we locate Veric's eloquent "histories" in our quotidian lives, "histories" traversing regional boundaries but speaking a cosmopolitan idiom now standard for postmodern verses in the Global North? How can the silenced histories of the poet and his readers/translators be excavated in so many points of transit in his passage from Aklan in neocolonial clocktime to the present global era of 9/11 terrorism, U.S. imperial wars in Afghanistan and Syria, drone warfare, Mamasapano carnage, and the interminable OFW diaspora? This book is thus an occasion for exchange, translation, and playing convivial language-games (as Wittgenstein envisaged it) for our newly-emerging lives. 